\title{
CDC37 Gene
}

National Cancer Institute

\section{Source}

National Cancer Institute. CDC37 Gene. NCI Thesaurus. Code C24281.

This gene regulates the progression of cells through the G1 phase of the cell cycle. 